\title{
Critical Pathways for Emergency Diseases Available in the Emergency and Critical Care Center
}

\author{
Takeshi Takahashi, Hiroshi Oiso, Masahiro Harada, Satoshi Hashimoto \\ Akiko Yoshioka, Shozo Kobori, and Hisayoshi Miyazaki
}

\begin{abstract}
It is necessary to utilize the critical path system effectively to improve efficiency and produce good quality medical treatment for emergency patients. In this study, we examined the application of critical paths to patients admitted urgently to our hospital and determined the types of critical paths necessary for emergency medicine. The mean critical path utilization rate for all admitted emergency patients was $32.4 \%$. Critical path utilization was low in the departments of internal medicine and psychiatry, but higher in the departments of cardiology, orthopedics and cardiothoracic surgery. The latter departments have both examination critical paths and operation critical paths. The most frequently used critical paths were those designed for patient observation such as critical path for observational hospitalization. Especially in the critical care center, the critical path use rate was poor at $22.4 \%$ and the most frequently used critical path was for acute phase hemorrhagic cerebrovascular disorder. Introduction of critical paths should enforce evidence-based medicine, increase the efficiency of business, improve team medicine, operation of informed consent, reduce the duration of hospitalization, effective cost-cutting measures, good quality and effective medical treatment. We should prepare for the series of critical paths for emergency diseases before the DPC System is introduced in emergency hospitals.
\end{abstract}

(JJAAM $2005 ; 16: 103-8$ )

Keywords: critical path, emergency medicine, emergency and critical care center, diagnosis procedure combination Accepted for publication on May 20, $2004 \quad$ (04-037)

\section{Introduction}

Our general hospital is located in the center of Kumamoto city, and has 550 beds. The hospital has become one of the most popular emergency hospitals in Kyusyu area in recent years, and approved as an emergency and critical care center in August 2003. We accept over 5000 emergency ambulances annually and over 600 of patients admitted from the emergency room every month. On the other hand, we energetically wrestle with the medical management to promote a critical path. A critical path defines the optimal sequencing and timing of interventions by physicians, nurses, and other staff for a particular diagnosis or procedure. Critical paths are de-

Corresponding author:

Prof. Takeshi Takahashi,

Emergency and Critical Care Center,

Kumamoto Medical Center, National Hospital Organization, 1-5 Ninomaru, Kumamoto City, Kumamoto 860-0008, Japan veloped through collaborative efforts of physicians, nurses, pharmacists, and others to improve the quality and value of patient care. They are designed to minimize delays and resource utilization and to maximize quality of care. Critical paths have been shown to reduce variation in the care provided, facilitate expected outcomes, reduce delays, reduce length of stay, and improve cost-effectiveness. The approach and goals of critical paths are consistent with those of total quality management (TQM) and can be an important part of an organization's TQM process ${ }^{1)}$. Critical path is the weapon necessary to provide good medical treatment, and several hospitals have adopted the critical path system in recent years. We introduced the critical path system in our hospital in 1999, and currently have 296 critical paths and using $45-50 \%$ of all in-patients. Naturally, it is also necessary to utilize the critical path system effectively to produce good efficiency and good quality of medical treatment for emergency patients. In this study, we examined the practical use of critical paths in patients admitted urgently to our hospital with the aim of defining the most suitable critical paths for emergency medicine. 
Table 1. Clinical conditions of patients admitted to critical care center from August 2003 to January 2004.

\begin{tabular}{lcc}
\hline Emergency and critical care center admission & $\mathrm{n}$ & $(\%)$ \\
\hline Cardiopulmonary arrest on arrival & 24 & 5.0 \\
Severe cerebrovascular disorder & 130 & 27.1 \\
Acute myocardial infarction, Heart failure & 65 & 13.5 \\
Dissection of aorta & 15 & 3.1 \\
Severe respiratory disorders & 60 & 12.5 \\
Severe pancreatitis & 6 & 1.2 \\
Acute abdomen requiring surgery & 30 & 6.2 \\
Severe metabolic disorders & 34 & 7.1 \\
Multiple trauma & 21 & 4.4 \\
Trauma requiring general anesthesia & 10 & 2.1 \\
Digit and Limb amputation & 0 & 0 \\
Extensive burn & 4 & 0.8 \\
Acute poisoning & 45 & 9.7 \\
Miscellaneous & 36 & 7.5 \\
\hline Total & 480 & 100 \\
\hline
\end{tabular}

Table 2. The critical path use ratio for emergency admitted patients over a 6-month period (from August 2003 to January 2004).

\begin{tabular}{lccc}
\hline & $\begin{array}{c}\text { Number of emergency inpatients for } \\
\text { whom critical }\end{array}$ & $\begin{array}{c}\text { Number of all emergency } \\
\text { inpatients (B) }\end{array}$ & $\begin{array}{c}\text { A/B } \\
(\%)\end{array}$ \\
\hline Internal medicine & 227 & 1040 & 21.8 \\
Cardiology & 87 & 176 & 49.4 \\
Pediatrics & 50 & 133 & 37.6 \\
Psychiatry & 23 & 145 & 15.9 \\
Surgery & 73 & 234 & 31.2 \\
Orthopedics & 206 & 256 & 80.5 \\
Brain surgery & 54 & 168 & 32.1 \\
Cardiosurgery & 22 & 22 & 100 \\
Urology & 12 & 88 & 13.6 \\
Obstet. and Gyne. & 23 & 71 & 32.4 \\
Dermatology & 8 & 51 & 15.7 \\
Otorhinolaryngology & 23 & 93 & 24.7 \\
Ophthalmology & 4 & 29 & 13.8 \\
Dental surgery & 2 & 12 & 16.7 \\
\hline Total & 814 & 2514 & 32.4 \\
\hline
\end{tabular}

Obstet: obstetrics, Gyne: gynecology

\section{Methods}

First we investigated all emergency patients admitted during a period of 6 months (from August 2003 to January 2004) to determine, the number of patients admitted to each section of the clinical departments and the rates of critical paths utilized, and examined concrete types of critical paths that are used for all patients. Next we exact the severe illness patients like those admitted to the critical care center. We calculated the number of those patients and examined the types of critical paths applied to patients. Classification of the diseases of patients admitted to critical care center was according to the Ministry of Health, Labor and Welfare classified list. 
Table 3. Critical paths applied on emergency admitted patients from August 2003 to January 2004.

\begin{tabular}{|c|c|}
\hline Name of critical path & $\mathrm{n}$ \\
\hline Critical path for observational hospitalization & 281 \\
\hline Critical path for cardiac catheterization & 72 \\
\hline Critical path for acute phase hemorrhagic cerebrovascular disorder & 66 \\
\hline Critical path for fixation of femoral neck fracture & 63 \\
\hline Critical path for rest cure & 36 \\
\hline Critical path for infantile pneumonia and bronchitis & 19 \\
\hline Critical path for artificial replacement of femoral head & 19 \\
\hline Critical path for acute alcohol poisoning & 15 \\
\hline Critical path for infantile asthma-like bronchitis & 13 \\
\hline Critical path for acute intrapelvic inflammation & 13 \\
\hline Critical path for athero-thrombotic brain infarction & 9 \\
\hline Critical path for cardiogenic brain infarction & 9 \\
\hline Critical path for lacuna infarction & 8 \\
\hline Critical path for unconsciousness attack & 7 \\
\hline Critical path for virus colitis & 7 \\
\hline Critical path for laparoscopic omentopexy & 7 \\
\hline Critical path for sudden deafness & 6 \\
\hline Critical path for febrile convulsion & 6 \\
\hline Critical path for appendectomy & 6 \\
\hline Critical path for inflammation of extremities & 6 \\
\hline Critical path for herpes zoster & 6 \\
\hline Critical path for external fixation of tibia fracture & 5 \\
\hline Critical path for fixation of ankle fracture & 5 \\
\hline Critical path for compression fracture of lumber supine & 5 \\
\hline Critical path for percutaneous transcatheter cardiac angioplasty & 5 \\
\hline Critical path for facial palsy & 5 \\
\hline Critical path for endoscopic variceal ligation & 5 \\
\hline Critical path for coronary-aorta bypass graft & 5 \\
\hline Miscellaneous & 105 \\
\hline Total & 814 \\
\hline
\end{tabular}

\section{Results}

1) Table 1 lists the conditions of patients admitted to our critical care center. Classification of the disease was based on the Ministry of Health, Labor and Welfare classification system. The most common conditions were severe acute cerebrovascular disorders, acute myocardial infarction, and severe respiratory disorders.

2) The number of emergency patients admitted to each section of the clinical departments and the rates of critical paths utilized are shown in Table 2. The mean critical path utilization rate for patients admitted urgently was $32.4 \%$. The critical path utilization rate was low in the departments of internal medicine and psychiatry, but high in the departments of cardiology, orthopedics and cardiothoracic surgery, which had both examination critical paths and operation critical paths.

3) Table 3 lists the critical paths frequently used on all patients admitted urgently. The most frequently used critical paths were those designed for observation of patients such as critical path for observational hospitalization, critical path for acute phase hemorrhagic cerebrovascular disorder and critical path for rest cure. Critical paths designed for examinations and operations were also used such as critical path for cardiac catheterization and critical path for fixation of femoral neck fracture.

4) Critical paths applied to patients admitted to the critical care center are shown in Table 4. Critical path for acute phase hemorrhagic cerebrovascular disorder was used for 37 patients, mainly for patients with cerebral hemorrhage $(n=18)$ and subarachnoid hemorrhage $(n=6)$. Critical path 
Table 4. Critical paths utilized for emergency patients admitted to critical care center from August 2003 to January 2004.

\begin{tabular}{|c|c|}
\hline Name of critical path and clinical conditions & $\mathrm{n}$ \\
\hline Critical path for acute phase hemorrhagic cerebrovascular disorder & 37 \\
\hline Cerebral hemorrhage & 18 \\
\hline Subarachnoid hemorrhage & 6 \\
\hline Brain contusion & 3 \\
\hline Traumatic subarachnoid hemorrhage & 3 \\
\hline Acute subdural hemorrhage & 3 \\
\hline Miscellaneous & 4 \\
\hline Critical path for cardiac catheterization & 25 \\
\hline Acute myocardial infarction & 15 \\
\hline Dissection of aorta & 6 \\
\hline Heart failure & 3 \\
\hline Pulmonary thromboembolism & 1 \\
\hline Critical path for observational hospitalization & 17 \\
\hline Acute poisoning & 10 \\
\hline Head injury & 3 \\
\hline Miscellaneous & 4 \\
\hline Critical path for laparoscopic omentopexy & 6 \\
\hline Critical path for cardiogenic brain infarction & 6 \\
\hline Critical path for chronic subdural hematoma & 4 \\
\hline \multicolumn{2}{|l|}{ Critical path for replacement of abdominal aorta } \\
\hline Rupture of abdominal aorta aneurysma & 3 \\
\hline Critical path for coronary-aorta bypass graft & 3 \\
\hline Miscellaneous & 15 \\
\hline Total & 116 \\
\hline
\end{tabular}

for cardiac catheterization was used for 25 patients, mainly for patients with acute myocardial infarction $(n=15)$ and dissection of the aorta $(n=6)$. Critical path for observational hospitalization was mainly used for patients with acute poisoning.

\section{Discussion}

Introduction of critical paths has proved to enforce evidence-based medicine, increase the efficiency of business, improvement of team medicine, operation of informed consent, reduction of duration of hospitalization, design of effective cost-cutting measures, good quality and good efficiency of medical treatment ${ }^{2-6)}$. Most critical paths are designed for surgery or orthopedics including operation or examination, while emergency admitted patients of surgical cases are minority ${ }^{7)}$. Although treatment of emergency patients varies according to the seriousness of the condition and urgency, the critical path use rate for emergency patients was poor at $32.4 \%$. Especially in the critical care center, the critical path use rate was low at $22.4 \%$.

There were several reports of experiences using critical paths for emergency diseases. Pelliccia et al introduced emergency critical path for ST-elevation myocardial infarction in their hospital in 1998. The rate of receiving primary angioplasty was elevated from $11 \%$ to $63 \%{ }^{8}$. 
Benenson et al described of their pneumonia clinical pathway that the mean time to antibiotics administration decreased from 315 minutes prepathway to 175 minutes during the first postpathway period $(\mathrm{p}<0.0001)$. And the percentage of patients who received antibiotics in the emergency department increased from 58\% prepathway to $94 \%$ postpathway $(\mathrm{p}<0.0001)^{9}$. Choong described that clinical pathway for fractured neck of femur had shorted the total stay 8.0 to 6.6 days $(\mathrm{p}=0.03)^{10}$. . Ross et al also indicated that critical pathway for stroke decreased the length of hospital stay to 6.33 from 7.52 days ${ }^{11}$, and critical pathway for pneumonia decreased to 7.11 from 9.07 days ${ }^{12}$.

Emergency hospitals can estimate the emergency special charge and regional supporting hospital charge, but they are obliged to reduce the period of hospitalization. However, the proportion of elderly people in the society is large at present, and hence most patients admitted to the emergency and critical care center are elderly patients who require longer hospitalization. Accordingly, emergency hospitals must step up plans together with sub-emergency hospitals in order to reduce the days of hospital stay. Hence, we established the medical cooperating critical paths, which are designed as treatment and rehabilitation programs for two hospitals (involvement of another hospital). These critical paths are mainly used for patients with apoplexy and femoral neck fracture ${ }^{5)}$.

The payment system called the diagnosis procedure combination (DPC), which is originated by Japanese government, was implemented in Japan medical school hospital and 81 other specific-functional hospitals in 2003. This payment system depends on the length of hospital stay and diagnosis and medical procedures, and differs from the existing payment system, which depends on a piece rate. Kiyama et al indicate that the new medical payment system should stimulate competition among hospitals. In order to decrease the length of stay, they developed clinical pathways for patients undergoing surgery, such as laparoscopic cholecystectomy, gastrectomy, and inguinal hernia operations, as well as clinical protocols for the surgical procedures, such as percutaneous transhepatic cholangiodrainage and percutaneous endoscopic gastrostomy ${ }^{13)}$. To prepare for DPC, standardization of medical care, shortening the average length of stay within all hospitals, cost reduction, establishment of hospital networks, and an increase in new patients are critical issues. Cost management can be achived effectively by using the critical path ${ }^{14)}$.

In the initial stages, many critical paths were designed for examinations and operations because the design of such programs was simple and easy. However, most of emergency diseases is internal medicine diseases, it is very difficult to design and application of critical paths for internal medicine diseases ${ }^{15)}$. We should prepare for the series of critical paths for emergency diseases before the DPC System is introduced in emergency hospitals.

\section{References}

1) Coffey RJ, Richards JS, Remmert CS, et al: An introduction to critical paths. Qual Manag Health Care 1992; 1: 45-54.

2) Spath PL: Critical paths: maximizing patient care coordination. Todays OR Nurse 1995; 17: 13-20.

3) Kobori S, Yano M, Nomitsu I, et al: Improvement of medical quality by blood glucose control critical path. The Journal of Japan Society for Health Care Management 2002; 3: 262-6.

4) Kobori $S$, Takahashi $T$, Higashi $K$, et al: An application of critical path to type 2 diabetes mellitus. The Journal of Japan Society for Health Care Management 2003; 4: 292-6.

5) Nomura K: Critical path and regional Health care. The Journal of Japan Society for Health Care Management 2002; 2 : 314-9.

6) Hofmann PA: Critical path method: an important tool for coordinating clinical care. Jt Comm J Qual Improv 1993; 19: 235-46.

7) Kawashima K, Yano M, Fukutomi K, et al: Effect of introduction of critical path made for observational short-term hospitalization at the emergency center. The Journal of Japan Society for Health Care Management 2002; 2: 347-50.

8) Pelliccia F, Cartoni D, Verde M, et al: Critical pathways in the emergency department improve treatment modalities for patients with ST-elevation myocardial infarction in a European hospital. Clin Cardiol 2004; 27: 698-700.

9) Benenson R, Magalski A, Cavanaugh S, et al: Effect of a pneumonia clinical pathway on time to antibiotic treatment, length of stay, and mortality. Acad Emerg Med 1999; 6: 1243-8.

10) Choong PF, Langford AK, Dowsey MM, et al: Clinical pathway for fractured neck of femur: a prospective, controlled study. Med J Aust 2000; 172: 423-6.

11) Ross G, Johnson D, Kobernick M: Evaluation of a critical pathway for stroke. J Am Osteopath Assoc 1997; 97: 26972.

12) Ross G, Johnson D, Kobernick M, et al: Evaluation of a critical pathway for pneumonia. J Healthc Qual 1997; 19: 22-9.

13) Kiyama $T$, Tajiri $T$, Yoshiyuki $T$, et al: Implementation of the diagnosis procedure combination in specific-function hospitals. J Nippon Med Sch 2004; 71: 217-20.

14) Hakamada $K$, Sasaki $M$ : The role of the critical path in a new hospital pament system according to a diagnosis procedure combination in Japan. Gan To Kagaku Ryoho 2004; 31: 
1179-85.

15) Muto M: A new international trend of hospital payment system and diagnosis procedure combination in Japan, with spe- cial reference to DPC critical path. The Journal of Japan Society for Health Care Management 2003; 4: 275-84.

\section{原著論文}

\section{救命救急センターにおいて使用されている 救急疾患群クリティカルパスについての検討}

$\begin{array}{lrrrrrr}\text { 高橋 } & \text { 毅 } & \text { 大礒 } & \text { 洋 } & \text { 原田 } & \text { 正公 } & \text { 橋本 } \\ \text { 吉岡 } & \text { 明子 } & \text { 小堀 } & \text { 祥三 } & \text { 宮崎 } & \text { 久義 } & \end{array}$

要旨 年々増加し重症度も高まっている救急患者に対し，効率的でしかも質の保証された医療を提供するにはク リティカルパスの使用が大変有用である。そこで，当院に緊急入院となった救急患者に実際に使用されたパスの 調査を行い, 救急医療に必要とされているクリティカルパス群の検討を行った。現在当院は296種のクリティカ ルパスを有しており, 病院全体での使用率は 40-50\%であるが, 緊急入院となった救急患者へのクリティカルパ ス使用率は $32.4 \%$ にどまった。使用率が高かった診療科は, 検查用クリティカルパスや手術用クリティカルパ スを有する循環器科 (49.4\%), 整形外科 (80.5\%), 心臓血管外科 (100\%)で, 逆に低かった診療科は内科 $(21.8 \%)$, 精神科 (15.9\%)であった。もっとも多く使用されたパスは，経過観察入院用パスであり救急医療を行うにあたっ て大変有用であることがわかった。重症患者が入院する救命救急センター内でのクリティカルパスの使用率はさ らに低く22.4\%であり，その中でも多く使用されたのは出血性脳血管障害用クリティカルパス，心臓カテーテル 検査用クリティカルパスであった。クリティカルパスの導入により, 根拠に基づく医療の実施，業務の効率化， チーム医療の向上, インフォームドコンセントの充実, 在院日数の短縮, コスト削減の効果が得られ, 入院にお ける良質で効率的な医療を提供することができる。今後, 診断群別包括払い制度が救急病院へ導入される前に救 急疾患群に対するクリティカルパスを整備しておく必要がある。

(日救急医会誌 $2005 ; 16: 103-8$ )

キーワード：クリティカルパス, 救急医療, 救命救急センター, 診断群別包括払い

原稿受理日：2004 年 5 月 20 日 (04-037)

国立病院機構熊本医療センター救命救急センター 